\title{
Students' Beliefs Regarding the Use of E-portfolio to Enhance Cognitive Skills in a Blended Learning Environment
}

https://doi.org/10.3991/ijet.v14i02.8288

\author{
Prakob Koraneekij, Jintavee Khlaisang $\left({ }^{\varpi}\right)$ \\ Chulalongkorn University, Bangkok, Thailand \\ jintavee.meg.chula.edu
}

\begin{abstract}
This paper reports on a quantitative study on ICT readiness among undergraduate students in Thailand, students' beliefs about use of e-portfolios in the Blended Learning Environment (BLE), and students' beliefs about using e-portfolios to enhance their cognitive skills in the BLE. The sample group comprised 360 undergraduate students, divided by study fields. The data collection tool was a questionnaire of students' beliefs. The reliability value of the questionnaire was 0.889 . Data was analyzed using statistical analysis and f-test. The beliefs and needs were ranked by PNI modified. The research found that every student had a computer connected to the Internet. The analysis results of students' beliefs about the use of e-portfolios in the BLE were positive and the top five results were: (1) learning by creating work, (2) enhancing creativity, (3) enhancing the problem solving skill, (4) enhancing critical thinking, and (5) enhancing authentic assessment. The current state of using eportfolios to enhance cognitive skills in the BLE was at average level, while the needs were at the high level.
\end{abstract}

Keywords-Belief, Blended Learning, E-portfolio, Cognitive skills

\section{$1 \quad$ Introduction}

Global society in the 21 st century is fast changing. The advancement of Information and Communication Technology (ICT) has greatly connected the world and sped up communication. As a result, the lifestyles and learning styles of students have changed. The modern learning style requires learners to establish a network of learning, without any boundaries, and which is fully supported by the use of ICT in different study fields in Higher Education Institutions (HEIs), whether education, engineering, linguistics, or any other area [1][2].Concurrently, cognitive skill is now considered one of the most important skills among the four skills for learning and teaching in the 21 st century [3]. According to the literature, several educators focused on using ICT to enhance cognitive skills. For example,Laux and Stoten [4], Barrot[5], and Bleasel et al.,[6] all studied the use of technology to improve critical thinking, problem solving, and creative thinking skills. Porter, Kleve and Palermo [7] emphasized the use of technology in enhancing creative thinking skill. Much research also studied 
the learning achievement results of technology skills and positive attitudes toward learning through use of the e-portfolio and BLE [4][5][8][9][10][11][12][13].

Additionally, research studies have addressed belief in teaching and the use of technology. A positive relationship has been established between teaching and the use of technology[14][15][16]. Thus, beliefs, values, feelings, and attitudes comprise the student's affective domain important to learning[17]. Jaimun[18] and Sophonhiranrak[19] proposed that attitude variables and students' experience can lead to selfdirected learning and promote online and blended learning effectively. Phommanee[20] studied the factors affecting learning via website, such as e-learning, BLE, online learning, etc. The research found that the student's attitude and beliefs as well as technological skill affected online learning at relatively high and high levels, respectively. In addition, these student factors accounted for the cognitive skill at a relatively high level, and that the learning environment, achievement motivation, attitude, personality, and teaching strategies influence critical thinking at the high level. However, there exists a gap in research on students' beliefs about the use of technology that enhances cognitive skills and how e-portfolio and blended learning can develop these skills, especially in the BLE in terms of its benefit on the flexibility and expansion of their knowledge via the online learning community. Such research could ascertain how valuable classroom time could be used for learners to practice these skills and build the necessary learning attitudes. This can enhance learning capacity, especially cognitive skills, for learners [21][22]. E-portfolio can be used for the Blended Learning Environment (BLE) and effective online learning since it has been widely used to develop learning achievement and cognitive skills $[7][4][5][6][23][24]$.

A variety of research identifies students' beliefs as possibly having influenced the use of ICT in learning over the past ten years [14][16][15][25][26][27][28][29]. Despite belief in using ICT having been studied extensively in HEIs, belief in using ICT to develop e-portfolios to enhance cognitive skills has found to be limited. The aforementioned literature and related research identifies the importance of studying students' beliefs about the use of e-portfolios in BLEs to enhance cognitive skills. The findings from this study will contribute to the field of educational technology in extending the understanding of the adoption of e-portfolios in the BLE to enhance the cognitive skills of students in many countries.

\section{$2 \quad$ Literature Review}

\subsection{Students' beliefs}

From the review of the literature on belief, the research was found to focus on belief in teaching and the use of technology. A positive relationship has been established between teaching and the use of technology [14][16][15][25][26][27][28][29]. Beliefs, values, feelings, and attitudes comprise the student's affective domain amd the importance for learning [17]. Jaimun[18] and Sophonhiranrak[19] proposed that attitude variables and student's experience can lead to self-directed learning and promote 
online and blended learning effectively. Phommanee[20] studied the factors affecting learning via web-based instruction. The research found that the student's attitude and belief as well as technological skill affected online learning at relatively high and high levels, respectively. In addition, these student factors accounted for cognitive skill at a relatively high level and that learning environment, achievement motivation, attitude, personality, and teaching strategies influence critical thinking and creative thinking at a high level.

\subsection{Electronic portfolio}

The roles of electronic portfolio (e-portfolio) in higher education to enhance learning have been addressed in different parts of the world, including Europe, Asia, Australia, and America [30][31][32][4][5][6][7][33]. The theoretical frameworks used in the study are authentic assessments and constructivist which are based on student assessments from learning evidence concerning, both assignments and processes. This is relevant to the abovementioned research on student ability in developing and presenting with the e-portfolio which will help to promote the learning result, practice result, and learning from reflection. Also, it promotes learning analysis which enhances quality and ability in assessing real situations. In addition, it develops knowledge and thinking skills, including critical thinking and problem solving skills $[4][5][6][7][33]$.

Barrett [30] and Koraneekij [33] provided similar definitions of e-portfolio as the systematic collection of works using computer technology and the Internet. It allows learners to store and collect different types of media such as text, audio, photos, and animations. Students can take part in determining and choosing the content and assessment as well as self-assessment, which focuses on reflecting upon the development and learning outcome of students. Research has investigated the effectiveness of e-portfolio used in higher education. In Australia, Porter et al. [7] conducted a comparison study of blended learning with two types of e-portfolio - in the Moodle eportfolio and Mahara e-portfolio. It was found that the learning result and creativity can be developed and presented using e-portfolio. Hallam and Creagh [24] studied the current conditions of the uses of e-portfolio of higher education students in Australia. They discovered that the e-portfolio was widely used and it employed a number of technologies. Bleasel et al. [6] gathered feedback on the use of the e-portfolio in medical long cases in a graduate medical program. The e-portfolio was deemed a valuable tool, with recommendations that it should be user friendly and easy to access. In the U.S., Laux and Stoten[4] studied e-portfolios and nurse students. They discovered that the e-portfolio was a tool that showed the learning results of nurse students. Studying the development and use of e-portfolios in a large medical school in the U.S., O'Brien et al. [23] found that most students passed the criteria. In sum, the above literature review indicates that most e-portfolios can be used in the BLE and online learning effectively by using learning achievement results, positive attitudes, and creative thinking.

Studies on e-portfolios in enhancing cognitive skills and higher order thinking skills have also been addressed. It was found that the e-portfolio helped enhance criti- 
cal thinking skills, problem-solving skills, technology skills, learning achievement, and creative thinking. In Asia, Barrot[5] studied the use of the e-portfolio with and Facebook for students who studied English as a second language on a writing course in the Philippines. The study garnered positive feedback toward the writing practice of students. Koraneekij [33] studied the development of the e-portfolio by selfassessment to enhance the critical thinking skills of student teachers. The study revealed that student teachers developed greater critical thinking skills after the experiment at a statistically significant level. Shuyan[8] studied the learning processes used in the development of the e-portfolio of graduate students in the educational technology field. They concluded that the e-portfolio helped students to develop their knowledge and technology skills as well as critical and problem-solving skills. In Europe, Van der Schaaf et al. [34] studied the role of e-portfolios in enhancing learning analysis which improved the quality and ability of assessing the real situation and expert assessments in education institutes in a sample comprising 121 students and 30 instructors from 5 institutes in Netherlands. They surmised that e-portfolios and student analysis were successful when developed and used in real situations. Koraneekij [33] studied the development of the e-portfolio by self-assessment to promote the critical thinking of student teachers. Shuyan [8] studied the learning process occurring during the development of the e-portfolio and found that the e-portfolio helped students develop critical thinking and problem-solving skills. Porter et al. [7] found that learning outcome and creativity can be developed and presented using e-portfolio. Thus, this research focuses on cognitive skills particularly critical thinking and problem solving skills. According to the literature, these skills can be measured by the use of e-portfolios from the records and evidence which then present the learning outcomes of these cognitive skills. This is because it allows learners to enhance their knowledge and understanding, and develop analysis and synthesis skills and apply knowledge and critical thinking [31][32]. Instructors and peers can send feedback on the assessments via the e-portfolio which enables learners to improve their work and cognitive skills. To introduce a new tool or innovation for learners, the most important thing is the learners' beliefs and attitudes.

\subsection{Blended learning environment}

Several research works have investigated the different types of Blended Learning Environment (BLE) that influence the various types of learning outcomes including knowledge creation, cognitive skills, as well as other types of competencies related to the students' desired learning outcomes [11][12][13][35][9]. Khlaisang [35] developed a constructivist BLE with cognitive tools to enhance the learning of higher education learners. Further research by Khlaisang \& Koraneekij [9]developed the BLE using an Online Interactive Reflective Learning Log (OIRL) that enhanced the knowledge pursuit and retention of students in Thailand.

Kintu, Zhu, and Kagambe[11]studied BLE to analyze the relationship between the characteristics and background of students and the design of the features and learning results. The sample comprised 238 students from Uganda, Africa. The research found that the characteristics and backgrounds of some students and the designed features 
can determine the learning results of students in BLE at a statically significant level. Nakayama, Mutsuura, and Yamamoto [12] studied the learning ability and learning attitude of students by writing a journal on BLE. The researchers analyzed the contents of the journals to estimate the scores from the final exam and to develop the learning ability of higher education students in Japan. They discovered that the activities and learning method of writing a journal correlated and predicted the test scores. In Europe, Vo, Zhu and Diep[13] studied the effect of BLE on the learning results of higher education students by comparing these results with traditional learning by reviewing 122 research articles. Their research concluded that BLE was more related to the learning improvement of students in STEM fields compared to traditional learning. This is consistent with the research by Thorne et al. [36] which studied the creation of variables related to the curriculum evaluation of Advanced Life Support (ALS) that improved the learning outcome of students participating in e-Learning Advanced Life Support (e-ALS) in the UK. They found that time spent accessing e-learning did not have any effect on learning result. However, the BLE helped students adjust their learning experience via e-learning to match their needs. Aydin[37] studied learning environment via Facebook in Turkey. The results of the research are not conclusive because of the lack of research on educational environments using Facebook as an educational resource. However, current research shows that Facebook should be more useful as an educational tool. The work of Pilgrim et al. [38] studied the perspectives of recent graduates from the Blended Learning Curriculum for teachers specializing in children with learning and behavioral problems in New Zealand. The results indicated that program performance was recognized by participants as important for working with children with such difficulties. They also saw that they could develop the capacity to develop their teaching competencies well. In addition, to address the effectiveness of BLE it is important to explore the existing pedagogy used in BLE to enhance cognitive skills. For example, Bonk and Graham [39] studied the types of online learning in higher education that were well known among 544 online instructors. The first three were group problem solving and collaborative tasks (65.4\%), problembased learning $(58.1 \%)$, and discussion (43.6\%). The above section has highlighted the benefits and pedagogy used in BLE in general. In sum, the need to explore particular pedagogies to be used in BLE to enhance cognitive skills is necessary.

\subsection{Pedagogy used in BLE to enhance cognitive skills}

As for the pedagogy used in the BLE to enhance cognitive skills, research has applied various learning theories, methods, and tools. For example, Khlaisang [35]took a constructivist approach with cognitive tools, and Khlaisang and Koraneekij [9] used reflective journal for interactive learning. Research by Bonk and Graham [39] found that the three most widely used teaching methods among instructors were: (1) group problem solving and collaborative tasks, (2) problem-based learning, and (3) discussion. One study on pedagogy found that problem-based learning and project-based learning also helped enhance cognitive skills [40][41][42][43][44][45][46].

Pedagogy is knowledge in instruction that helps learners develop knowledge in accordance with the objectives. It is derived from the widely accepted concepts, princi- 
ples, philosophies, and theories of educators which have been scientifically tested and researched [47][17]. This research focuses on two types of pedagogy to develop cognitive skills, namely, problem-based learning (PBL) and project-based learning $(\mathrm{PjBL}) . \mathrm{PBL}$ is student-centered learning using problems from real contexts. Students are given the problem and find solutions by working together and using existing knowledge as well as acquiring extra knowledge [48]. Some research has centered on the use of PBL to improve learning outcomes and positive attitudes within learning. [40] studied mind maps and PBL and enhancing the creativity and learning motivation of students. Hallinger and Bridges [49] studied the result of the use of PBL in developing the leadership skills of educational staff. Smith and Hung [42] indicated that PBL helps students better improve their computer skills than learners learning by lecture. This concurs with Hou et al. [50], who by looking at the development and evaluation of the use of web-based mind map tools in teaching by PBL, found that learners had positive attitudes towards learning when using this learning method.

Based on the literature review, PjBL is defined as the instructional model which allows students to study problems and perform research, collect data, and perform tasks. The learning process is systematic from start to finish. Then knowledge is applied to maximize the benefits [51]. Research has investigated the role of PjBL in improving learning outcomes and positive attitudes in learning. Chu et al. [52] conducted a comparative study of perception and action on using wikis in PjBL through the use of the triangulation methodology. It was found that most students had positive attitudes toward the use of wikis, most effectively in the areas of "motivation" and "knowledge management". Han [53] studied student's attitudes toward STEM learning using PjBL in South Korea. This work showed that student attitudes towards PjBL comprised elements such as learning with technology, self-directed learning, and activity-based learning which helped direct students with good attitudes to more intentional and engaged learning. Wu [44] studied mind map collaborative learning to promote creative learning activities and strengthen student capacity to create innovation in Taiwan. The results showed that this learning method can improve learning effectiveness, enhance innovative thinking skill, and promote the creative side. In the U.S. Davis, Pauls, and Dick [45] studied PjBL in environmental chemistry labs for undergraduate students to develop a method for evaluating pesticides. The result showed that PjBL improved the students' learning ability in various areas. Ludwig, Tongen and Walton [46] conducted a comparative study of teaching methods by using PjBL that enhanced students' abilities in mathematics and biology in the U.S. The research concluded that the first approach allowed students to select projects based on individual interests, which enabled them to apply mathematical and biological models. The second approach helped students select projects that focused on the most common biological patterns that motivated unity among students. Biasutti and El-Deghaidy[54] also studied the use of wikis as an online teaching tool in PjBL for university instructors. The researcher divided trainees into small groups in a wiki-based environment within the Moodle platform in Italy. They found that collaborative activities and online activities could develop work learning effectiveness and the ability of instructors in designing projects within the interdisciplinary context. Ruggiero and Boehm [55] investigated the relationships between intern students, clients, and mentors which led to the suc- 
cessful completion of an internship program in a virtual environment in designing the $\mathrm{PjBL}$ in the UK. The research found that the success of the project related to the understanding between intern students, mentors, and clients. It also led to the design, development, and research methodology.

\subsection{Cognitive skills}

As mentioned, the most immediate cognitive skills for the 21 st century learning are critical thinking, problem-solving, and creativity [56]. Critical thinking skill is the capacity to consider an issue reasonably, using information, situation, and experience to decide what to believe or what should be done and make a reasonable conclusion [57][58][56]. Problem-solving skill can be defined as the understanding of situation by using behavior patterns, methods, and procedures to study the problems to achieve the desired goals. It is the thinking process that requires intelligence to solve problems and achieve the expected goals. [59][60][61][56]. Creativity is the ability to imagine, think outside the box, and think of new possibilities to create things or solve problems [62][63][56]. In the Thai context, the Thai Qualifications Framework for Higher Education (TQF: HEd) recognizes the need for cognitive skills by requiring learners to gain experience during higher education in the five most significant and urgent cognitive skill areas as the minimum [35].

\section{Aim of the Study}

From the aforementioned literature and related research, the aim of the current study was to examine students' beliefs about the use of e-portfolio in a BLE to enhance cognitive skills. The following research questions were used to guide this study:

- What is the ICT readiness among undergraduate students in Thailand?

- What are the students' beliefs about the use of e-portfolios in BLE in Thailand?

- What are the students' beliefs about using e-portfolios to enhance their cognitive skills in BLE?

\section{Method}

\subsection{Participants}

The sample group comprised 360 undergraduate students at the Faculty of Education, Chulalongkorn University in Thailand who were selected and invited to participate in the study. The size of the sample group was calculated using the $\mathrm{G}^{*}$ Power program with the confidence level at $95 \%$, error at $\pm 5 \%$, power of test at 0.95 , moderate effect size (.25), and 8 analysis groups [64]. Stratified random sampling was based on students' majors, including Secondary Education (Science Education), Secondary Education (Humanities and Social Sciences), Early Childhood Education and 
Paper-Students Beliefs Regarding the Use of E-portfolio to Enhance Cognitive Skills...

Elementary Education, Non-formal Education, Art and Music Education, Business Education, Health and Physical Education, and Educational Technology.

\subsection{Instrument}

The instrument used in the study was a questionnaire on the student's beliefs. It consists of 3 major parts: (1) demographic information about the use of ICT, (2) students' beliefs about learning in a BLE, and (3) students' beliefs about using e-portfolios to enhance their cognitive skills in a BLE. The process of creating the survey included first studying the concepts, theories, and related research to define the conceptual framework and determine the scope of questions. Then, the draft questionnaire was reviewed by three experts to check the content and language as well as the completeness and coverage of questions. The questionnaire was pilot tested on 30 students with the same characteristics as the sample group. Finally, the questionnaire was validated with Cronbach's alpha coefficient with a reliability value of 0.889 .

\subsection{Data collection and analysis}

The questionnaire data was collected by sending a request letter and coordinating with the dean of the faculty in which the sample group was studying. Then, the researcher sent the questionnaire to the sample group, collected and counted the returned questionnaires. The complete questionnaires were collected to analyze the data using statistical analysis (F-test). In addition, PNI modified was applied with the aim of comparing the current states, expected states, and prioritizing the need value from the highest to the lowest. Wongwanich[65] used PNI modified for needs assessment research based on the two grounded concepts of discrepancy and importance. Discrepancy was defined as the comparison between the current states and expected states, while importance was defined as needs prioritization. The results were presented in the number form of 1 to $n$, from the highest to the lowest, representing the most important to the least important respectively.

\section{$5 \quad$ Results}

In the following section, the research findings are aligned with the research questions as follows.

\subsection{Demographic information of the use of ICT in the BLE}

The respondents were 360 undergraduate students. Most were female, accounting for $66.4 \%$, and studying in the third year $(26.9 \%)$. Most of them $(18.9 \%)$ were studying the Secondary Education major (Humanities - Social Sciences). As for the use of computer and Internet, it was found that all respondents had their own computer and could connect to the Internet. Most of them had between 1 and10 years of experience in using a computer, accounting for $62.5 \%$, and between 1 and 10 years of experience 
using the Internet, accounting for $78.9 \%$. Most respondents used the Internet from 1 to 20 times per week (93.3\%). The number of hours spent on the Internet was between 1 and 10 hours, accounting for $98.9 \%$.

As for the readiness of computer (hardware), it was found that most respondents had their own computers or notebooks (99.2\%). All respondents have used ICT for learning. Most respondents used a computer for doing reports, accounting for $98.6 \%$. All respondents had knowledge in word processing programs. The details about the readiness for using technology for learning and developing an e-portfolio are shown in figures 1-3.

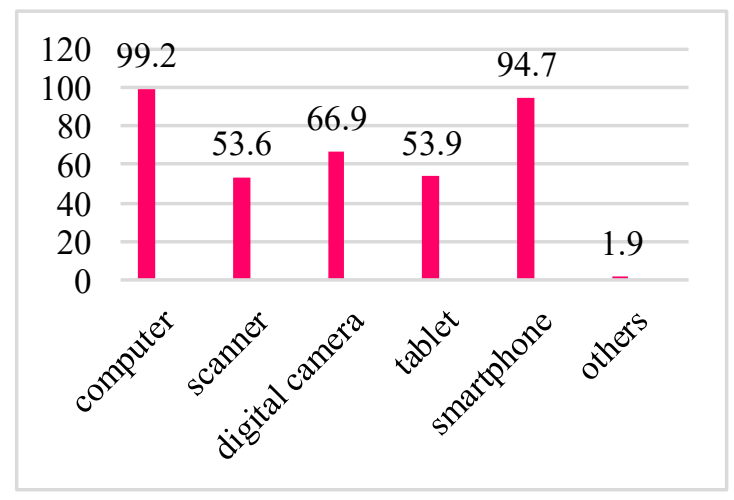

Fig. 1. Technological readiness to develop an e-portfolio (Percentage)

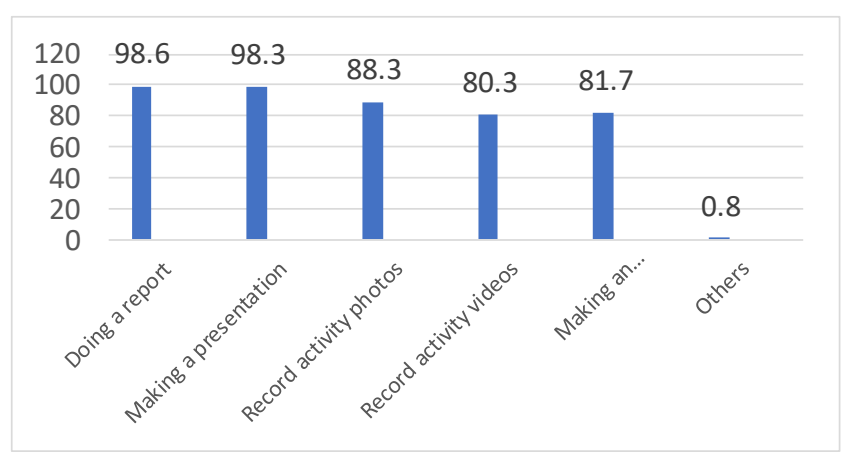

Fig. 2. The use of technology in learning and developing an e-portfolio (Percentage) 


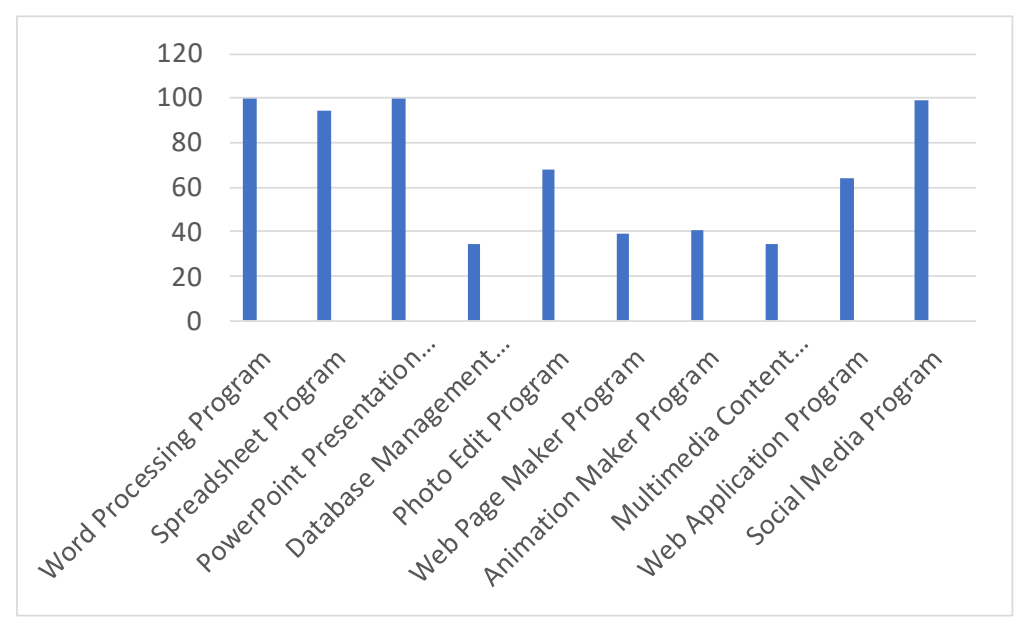

Fig. 3. Competency in using computer software in learning and developing an e-portfolio (Percentage)

\subsection{Students' beliefs about the use of e-portfolios in the BLE in Thailand}

Analysis of the results of students' beliefs about the use of e-portfolios in the BLE to enhance their learning covered the five top areas as follows: (1) learning by creating work, (2) enhancing creativity, (3) enhancing problem solving skills, (4) enhancing critical thinking, and (5) enhancing authentic assessment.

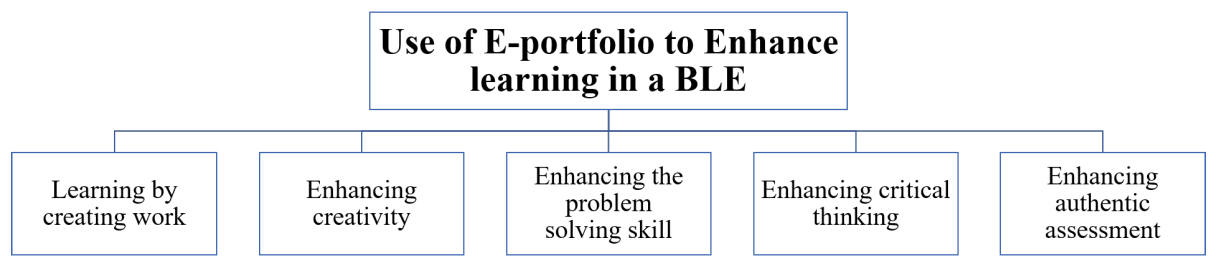

Fig. 4. Students' beliefs about the use of e-portfolios in the BLE in enhancing learning in the five top areas

The analysis of the differences of means in the use of e-portfolios in the BLE classified by independent variables found that the mean for the use of e-portfolio in BLE for student gender had statistically significant difference at the 0.05 level. Females had a higher mean than males. As for the study year, the mean of the second year students was higher than that of third-year students. When comparing study fields, it was found that Elementary and Primary Education had higher means than Non-formal Education, Secondary Education (Sciences), and Arts and Music Education. Educational Technology had a higher mean than Secondary Education (Sciences) and Arts and Music Education as detailed in table 1. 
Paper-Students Beliefs Regarding the Use of E-portfolio to Enhance Cognitive Skills...

Table 1. Analysis of the results of the differences of mean in the use of e-portfolios in the BLE classified by independent variables

\begin{tabular}{|c|c|c|c|c|c|c|c|c|}
\hline Variables & Details & & SD & $\begin{array}{l}\text { Levene's } \\
\text { test }\end{array}$ & sig & $\mathbf{F}$ & sig & Results \\
\hline \multirow[t]{2}{*}{ Gender } & Male (M) & 3.58 & .636 & \multirow[t]{2}{*}{.194} & \multirow[t]{2}{*}{.660} & \multirow[t]{2}{*}{6.442} & \multirow[t]{2}{*}{.012} & \multirow[t]{2}{*}{$\mathrm{F}>\mathrm{M}$} \\
\hline & Female (F) & 3.75 & .556 & & & & & \\
\hline \multirow[t]{5}{*}{ Year } & First year & 3.67 & .600 & \multirow[t]{5}{*}{2.332} & \multirow[t]{5}{*}{.056} & \multirow[t]{5}{*}{2.978} & \multirow[t]{5}{*}{.019} & \multirow[t]{5}{*}{$2>3$} \\
\hline & Second year & 3.84 & .605 & & & & & \\
\hline & Third year & 3.55 & .752 & & & & & \\
\hline & Fourth year & 3.68 & .440 & & & & & \\
\hline & Fifth year & 3.77 & .425 & & & & & \\
\hline \multirow[t]{8}{*}{ Study field } & $\begin{array}{l}\text { Secondary Education } \\
\text { (Sciences) (M1) }\end{array}$ & 3.53 & .374 & \multirow[t]{8}{*}{2.132} & \multirow[t]{8}{*}{.040} & \multirow[t]{8}{*}{4.296} & \multirow[t]{8}{*}{.000} & \multirow{8}{*}{$\begin{array}{l}\text { 1. M3 > } \\
\text { M1, M4, } \\
\text { M5 } \\
\text { 2. M8 > } \\
\text { M1, M5 }\end{array}$} \\
\hline & $\begin{array}{l}\text { Secondary Education } \\
\text { (Social Sciences) (M2) }\end{array}$ & 3.71 & .499 & & & & & \\
\hline & $\begin{array}{l}\text { Elementary Education } \\
\text { (M3) }\end{array}$ & 3.98 & .509 & & & & & \\
\hline & $\begin{array}{l}\text { Non-formal Education } \\
\text { (M4) }\end{array}$ & 3.63 & .410 & & & & & \\
\hline & $\begin{array}{l}\text { Arts \&Music Education } \\
\text { (M5) }\end{array}$ & 3.52 & .555 & & & & & \\
\hline & $\begin{array}{l}\text { Business Education } \\
\text { (M6) }\end{array}$ & 3.81 & .758 & & & & & \\
\hline & $\begin{array}{l}\text { Health \&Physical } \\
\text { Education (M7) }\end{array}$ & 3.50 & .981 & & & & & \\
\hline & $\begin{array}{l}\text { Educational Technolo- } \\
\text { gy (M8) }\end{array}$ & 3.93 & .559 & & & & & \\
\hline
\end{tabular}

5.3 Students' beliefs about using e portfolios to enhance their cognitive skills in the BLE

To answer the third research question on students' beliefs about using e-portfolios to enhance their cognitive skills in the BLE. This section is divided into 3 parts: (1) experience and beliefs in using e-portfolios, (2) current states and needs in using eportfolios to enhance cognitive skills in the BLE, and (3) current states in using eportfolios to enhance cognitive skills in the BLE. The details are as follows:

Experiences and beliefs in using e-portfolios: Regarding the experience and beliefs regarding use of e-portfolios in the BLE, it was found that most respondents have experience using portfolios $(94.2 \%)$. The number students who had never used eportfolio stood at $55.0 \%$, but most were interested in and of the belief that the eportfolio was one of the important ICT tools used in the BLE, at $73.6 \%$, because the e-portfolio can gather the work online, facilitate the storing of information, and back up work and thereby prevent the risk of data loss.

Current states and needs in using e-portfolios to enhance cognitive skills in the BLE: As for the differences in the means of the current states and expected states in using e-portfolios to enhance cognitive skills in the BLE, based on respondents' opinions all items had statistically significant difference at the 0.05 level. When analyzing 
the needs using PNI modified, the analysis results of the current states and expected states in using e-portfolios to enhance cognitive skills in BLE found that the top five needs were: (1) students can develop an e-portfolio for authentic assessment, (2) students develop an e-portfolio to evaluate their learning outcome in cognitive skill, (3) students have developed in their critical thinking skill from the instructor's teaching management, (4) students have developed their problem solving skill from the learning process, and (5) students learn from the BLE as shown in table 2. It can be seen that students need to use the e-portfolio to develop cognitive skill in two areas: critical thinking and problem solving, which were ranked in 4th and 5th place. Also, it was revealed that students need to use the e-portfolio to develop creative thinking skill (ranked 11th).

Table 2. Comparison of current states, expectation states, and prioritized needs in using an eportfolio to enhance cognitive skills in the BLE

\begin{tabular}{|l|c|c|c|c|c|c|c|c|}
\hline \multicolumn{1}{|c|}{ Question } & \multicolumn{2}{c|}{$\begin{array}{c}\text { Current } \\
\text { States }\end{array}$} & \multicolumn{2}{c|}{ Expected states } & t & sig & \multicolumn{2}{c|}{ Needs } \\
\cline { 2 - 8 } & & SD & & SD & & & PNI & Rank \\
\hline $\begin{array}{l}\text { Students can develop the e- } \\
\text { portfolio for authentic } \\
\text { assessment. }\end{array}$ & 2.24 & 1.476 & 4.10 & .852 & 23.403 & .000 & 0.83 & 1 \\
\hline $\begin{array}{l}\text { Students develop the e- } \\
\text { portfolio to evaluate their } \\
\text { learning outcome in cogni- } \\
\text { tive skill }\end{array}$ & 2.51 & 1.474 & 4.27 & .784 & 21.848 & .000 & 0.70 & 2 \\
\hline $\begin{array}{l}\text { Students have developed } \\
\text { their critical thinking skill } \\
\text { from the instructor's teach- } \\
\text { ing management. }\end{array}$ & 2.80 & 1.235 & 4.36 & .706 & 22.786 & .000 & 0.56 & 3 \\
\hline $\begin{array}{l}\text { Students have developed } \\
\text { their problem solving skill } \\
\text { from the learning process. }\end{array}$ & 2.95 & 1.101 & 4.26 & .753 & 20.568 & .000 & 0.44 & 4 \\
\hline $\begin{array}{l}\text { Students effectively learn in } \\
\text { the BLE. }\end{array}$ & 2.96 & 1.189 & 4.19 & .787 & 19.038 & .000 & 0.42 & 5 \\
\hline
\end{tabular}

* PNImodified $=(\mathrm{I}-\mathrm{D}) / \mathrm{D}$, When $\mathrm{I}$ is needs and $\mathrm{D}$ is current states. Items with higher PNImodified value are items with higher needs than those with lesser PNImodified

The mentioned results, element and learning processes of the use of e-portfolio to enhance cognitive skills, and relationship among students' beliefs about the use of e-portfolios in the BLE to enhance their cognitive skills and their needs are presented in table 3. 
Paper-Students Beliefs Regarding the Use of E-portfolio to Enhance Cognitive Skills...

Table 3. Summary of the proposed learning processes and elements, students' beliefs, and their needs about the use of e-portfolios in the BLE to enhance their cognitive skills

\begin{tabular}{|c|c|c|}
\hline $\begin{array}{l}\text { Proposed learning pro- } \\
\text { cess and elements }\end{array}$ & $\begin{array}{l}\text { Students' beliefs in using e- } \\
\text { portfolios to enhance cogni- } \\
\text { tive skills }\end{array}$ & $\begin{array}{l}\text { Students' needs in using e-portfolios to } \\
\text { enhance cognitive skills in the BLE }\end{array}$ \\
\hline $\begin{array}{l}\text { State objectives, content, } \\
\text { and e-port criteria } \\
\text { Elements: (1) (2) }\end{array}$ & $\begin{array}{l}\text { Enhancing authentic assess- } \\
\text { ment }\end{array}$ & $\begin{array}{l}\text { Students can develop the e-portfolio for } \\
\text { authentic assessment. } \\
\text { Students effectively learn in the BLE. }\end{array}$ \\
\hline $\begin{array}{l}\text { Create artifacts congruent } \\
\text { with cognitive skills in the } \\
\text { BLE. } \\
\text { Elements: (3) (5) }\end{array}$ & Learning by creating work & $\begin{array}{l}\text { Students develop the e-portfolio to evalu- } \\
\text { ate their learning outcome in cognitive } \\
\text { skill. } \\
\text { Students effectively learn in the BLE. }\end{array}$ \\
\hline $\begin{array}{l}\text { Collect artifacts or evi- } \\
\text { dence for working in the e- } \\
\text { portfolio. } \\
\text { Elements: (2) (3) }\end{array}$ & $\begin{array}{l}\text { Enhancing problem solving } \\
\text { skill }\end{array}$ & $\begin{array}{l}\text { Students have developed their problem } \\
\text { solving skill from the learning process. } \\
\text { Students effectively learn in the BLE. }\end{array}$ \\
\hline $\begin{array}{l}\text { Self-reflect upon and } \\
\text { assess artifacts. } \\
\text { Elements: (3) (4) }\end{array}$ & $\begin{array}{l}\text { Enhancing problem solving } \\
\text { skill }\end{array}$ & $\begin{array}{l}\text { Students have developed their problem } \\
\text { solving skill from the learning process. } \\
\text { Students effectively learn in the BLE. }\end{array}$ \\
\hline $\begin{array}{l}\text { Feedback by individuals } \\
\text { involved. } \\
\text { Elements: (3) (4) }\end{array}$ & Enhancing critical thinking & $\begin{array}{l}\text { Students have developed their critical } \\
\text { thinking skill from the instructor's teach- } \\
\text { ing management. } \\
\text { Students effectively learn in the BLE. }\end{array}$ \\
\hline $\begin{array}{l}\text { Select artifacts for presen- } \\
\text { tation in the e-portfolio. } \\
\text { Elements: (4) (6) }\end{array}$ & Enhancing creativity & $\begin{array}{l}\text { Students have developed their critical } \\
\text { thinking skill from the instructor's teach- } \\
\text { ing management. } \\
\text { Students effectively learn in the BLE. }\end{array}$ \\
\hline $\begin{array}{l}\text { Make the presentation e- } \\
\text { portfolio public. } \\
\text { Elements: }(4)(6)\end{array}$ & Enhancing creativity & $\begin{array}{l}\text { Students have developed their critical } \\
\text { thinking skill from the instructor's teach- } \\
\text { ing management. }\end{array}$ \\
\hline $\begin{array}{l}\text { Assess the potential impact } \\
\text { of the presentation portfo- } \\
\text { lio. } \\
\text { Elements: (1) (4) (6) }\end{array}$ & $\begin{array}{l}\text { Enhancing authentic assess- } \\
\text { ment }\end{array}$ & $\begin{array}{l}\text { Students can develop the e-portfolio for } \\
\text { authentic assessment. } \\
\text { Students effectively learn in the BLE. }\end{array}$ \\
\hline
\end{tabular}

Remark: The 6 elements include: (1) E-Port Objectives, (2) E-Port Artifacts, (3) Roles of Individuals, (4) Eport Tools, (5) BLE Pedagogy, and (6) E-Port Assessment

\section{Discussion}

The survey results of the use of ICT found that all undergraduate students had their own computer and could connect to the Internet. Likewise, for the readiness for computer use it was found that most students had their own computers or notebooks. All students were able to use Microsoft Word and PowerPoint presentation software as 
well as social media. It was found that most students have used an e-portfolio, accounting for $94.2 \%$, and $73.6 \%$ of respondents were interested in using e-portfolios because they can collect their work there online, facilitate the storing of data, and back up work which prevents the risk of data loss. This concurs with Hallam and Creagh[24], Bleasel et al. [66], and Laux and Stoten[4] who found there were several technologies used for the e-portfolio. It was recommended that the e-portfolio be user friendly and easy to access as well as facilitate data storage and present learning results.

The result analysis of the students' beliefs toward using e-portfolios to enhance cognitive skills in BLE was found to be positive. Students believe that the use of an eportfolio in the BLE enhances their creativity, critical thinking, and problem solving skills. This relates to the research of Koraneekij [33]which found that the e-portfolio helped improve critical thinking skill. The sample group in this study also believed that the e-portfolio was appropriate for use in the BLE to enhance not only ICT skills but also cognitive skills. This is similar to Shuyan[8]who found that the e-portfolio helped students to improve technological knowledge and skills as well as critical thinking and problem-solving skills. As for the differences in the mean of the current states and needs in using the e-portfolio to enhance cognitive skills in the BLE, based on respondents' opinions, all items had statistically significant difference at the level of 0.05 . It can be seen that the needs had higher mean than the current states. When

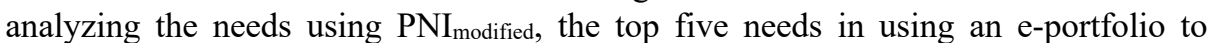
enhance cognitive skills were to develop an e-portfolio for authentic assessment, to develop an e-portfolio to evaluate their cognitive skill, to develop the critical thinking skill, to develop the problem solving skill from the learning process, and to effectively learn from BL, respectively. This concurs with Van der Schaaf et al. [34]who found that the e-portfolio was successful when it was developed and used in a real situation.

\section{Conclusion}

This research aimed to investigate ICT readiness among undergraduate students in Thailand, to examine students' beliefs about the use of the e-portfolio in the BLE in Thailand, and to evaluate students' beliefs about using the e-portfolio to enhance their cognitive skills in the BLE. Regarding students' use of computer and Internet, it was found that everyone had their own computer connected to the Internet. Most students also had between 1 and10 years experience in using a computer. Everyone used ICT in learning and was able to use Microsoft Word. The result analysis of the current state of using e-portfolios to enhance cognitive skills in the BLE found that, overall, the respondents' opinion was at the average level and the needs were at the high level. As for the differences in the mean of the current states and needs in using the eportfolio to enhance cognitive skills in the BLE, based on the respondents' beliefs, all items had statistically significant difference at the level of 0.05 . When analyzing the needs using $\mathrm{PNI}_{\text {modified, }}$ it was found that the students belief that developing an eportfolio for assessment and to enhance experience in using an e-portfolio in the BLE are necessary. This information is helpful for higher education institutes and instruc- 
tors who provide a BLE and are interested in assessing learning outcomes using eportfolios and need to develop students' cognitive skills. Future research could include an investigation into the development of an e-portfolio that supports application of the research results. Higher education students need to use an e-portfolio because of readiness in terms of tools and technology. Also, at present, MOOCs have also become popular. E-portfolios can certainly be developed to support this type of learning as well.

\section{Acknowledgement}

This manuscript was based on the research study titled "Development of Learning Outcomes Based E-Portfolio Model Emphasizing Cognitive Skills in the Pedagogical Blended Learning Environment for Undergraduate Students at the Faculty of Education, Chulalongkorn University" which was conducted by the authors of this paper during 2015-2017. The authors would like to express our sincere appreciation to Chulalongkorn University's RatchadapisekSompot fund in supporting this research study. Our appreciation also extends to Educational Invention and Innovation research unit, all involved experts, instructors, and students for their advice and support in developing new knowledge contributing to the field of educational technology and communications.

\section{References}

[1] Crosswell, L., \&Beutel, D. (2017). 21st century teachers : How non-traditional pre-service teachers navigate their initial experiences of contemporary classrooms. Asia-Pacific Journal of Teacher Education, 45(4), 416-43https://doi.org/10.1080/1359866X.2017.1312281

[2] Tuzlukova, V., Al Busaidi, S., \& Burns, S. L. (2017). Critical thinking in the language classroom: Teacher beliefs and methods. Pertanika Journal of Social Sciences and Humanities, 25(2), 615-633.

[3] Van Laar, E., van Deursen, A. J. A. M., van Dijk, J. A. G. M., \& de Haan, J. (2017). The relation between 21 st-century skills and digital skills: A systematic literature review. Computers in Human Behavior, 72, 577-588. https://doi.org/10.1016/j.ch b.2017.03.010

[4] Laux, M. \&Stoten, S. (2016). A Statewide RN-BSN Consortium Use of the Electronic Portfolio to Demonstrate Student Competency. Nurse Educator, 41(6): 275277.https://doi.org/10.1097/NNE.0000000000000277

[5] Barrot, J. S. (2016). Using Facebook-based e-portfolio in ESL writing classrooms: impact and challenges. Language, Culture and Curriculum 29(3): 286301.https://doi.org/10.1080/07908318.2016.1143481

[6] Bleasel, J., Burgess, A., Weeks, R., \&Haq, I. (2016). Feedback using an ePortfolio for medicine long cases: Quality not quantity. BMC Medical Education, 16(1) doi:10.1186/s12909-016-0801-3https://doi.org/10.1186/s12909-016-0801-3

[7] Porter, J., Kleve, S., \& Palermo, C. (2016). An exploratory study comparing two electronic portfolio approaches in undergraduate dietetic education. Nutrition and Dietetics, 73(3), 235-240. Porter, J., Kleve, S., \& Palermo, C. (2016). An exploratory study comparing two 
Paper-Students Beliefs Regarding the Use of E-portfolio to Enhance Cognitive Skills...

electronic portfolio approaches in undergraduate dietetic education. Nutrition and Dietetics, 73(3), 235-240 https://doi.org/10.1111/1747-0080.12210

[8] Shuyan, W. (2004). Learning experiences in developing electronic portfolios in a Master's educational technology program: A case study. Ohio University. DAI-A 65/05.

[9] Khlaisang, J. and Koraneekij, P. (2012). Development of Blended E-Learning Model Using Online Interactive Reflective Learning Logs to Enhance Faculty of Education Students' Inquiring Mind and Retention at Chulalongkorn University. Proceedings of the Fourth International e-Learning Conference 2012, the Office of the Higher Education Commission, Bangkok, Thailand, June 14, 2012.

[10] Gikas, J. \& Grant. M. M. (2013). Mobile computing devices in higher education: Student perspectives on learning with cellphones, smartphones \& social media. The Internet and Higher Education, 19: 18-26.https://doi.org/10.1016/j.iheduc.2013.06.002

[11] Kintu, M. J., Zhu, C., \&Kagambe, E. (2017). Blended learning effectiveness: The relationship between student characteristics, design features and outcomes. International Journal of Educational Technology in Higher Education, 14(1) https://doi.org/10.1186/s41239017-0043-4

[12] Nakayama, M., Mutsuura, K., \& Yamamoto, H. (2017). The possibility of predicting learning performance using features of note taking activities and instructions in a blended learning environment. International Journal of Educational Technology in Higher Education, 14(1): 6.https://doi.org/10.1186/s41239-017-0048-z

[13] Vo, H. M., Zhu, C., \& Diep, N. A. (2017). The effect of blended learning on student performance at course-level in higher education: A meta-analysis. Studies in Educational Evaluation, 53: 17-28.https://doi.org/10.1016/j.stueduc.2017.01.002

[14] Teo, T., Chai, C. S., Hung, D., \& Lee, C. B. (2008). Beliefs about teaching and uses of technology among pre-service teachers. Asia-Pacific Journal of Teacher Education, 36(2), 163-174. https://doi.org/10.1080/13598660801971641

[15] Chai, C. S., Wong, B., \&Teo, T. (2011). Singaporean pre-service teachers' beliefs about epistemology, teaching and learning, and technology. Teacher Development, 15(4), 485498. doi:10.1080/13664530.2011.635266https://doi.org/10.1080/13664530.2011.635266

[16] Chai, C. S., Hong, H., \&Teo, T. (2009). Singaporean and Taiwanese pre-service teachers' beliefs and their attitude towards ICT use: A comparative study. Asia-Pacific Education Researcher, 18(1), 117-128. Retrieved from www.scopus.com.

[17] Chai, C. S., Hong, H., \&Teo, T. (2009). Singaporean and Taiwanese pre-service teachers' beliefs and their attitude towards ICT use: A comparative study. Asia-Pacific Education Researcher, 18(1), 117-128. Retrieved from www.scopus.com.

[18] Jaimun, P. (2004). The development of knowledge management systems of local wisdom for Rajabhat Universities. Faculty of Education, Chulalongkorn University.

[19] Sophonhiranrak, S. (2009). Blended learning instruction factors affecting self-directed learning of undergraduate students. Faculty of Education, Chulalongkorn University.

[20] Phommanee, W. (2011). Factors effecting students learning results in web-based instruction: a meta-analysis. Faculty of Education, Chulalongkorn University.

[21] Khlaisang, J. and Koraneekij, P. (2009). Pedagogy-Based Hybrid Learning: from concept to practices. Faculty of Education, Chulalongkorn University Journal, 38 (1), 93-108.

[22] Bonk, C. J. \& Graham, C. R. (2006). The handbook of blended learning. San Francisco, CA: Pfeiffer.

[23] O'Brien, C. L., Sanguino, S. M., Thomas, J. X., \& Green, M. M. (2016). Feasibility and Outcomes of Implementing a Portfolio Assessment System Alongside a Traditional Grading System. Acad Med 91(11): 1554-1560. https://doi.org/10.1097/A $\underline{\text { CM.0000000000001168 }}$ 
Paper-Students Beliefs Regarding the Use of E-portfolio to Enhance Cognitive Skills...

[24] Hallam, G. \& Creagh, T. (2010). ePortfolio use by university students in Australia: a review of the Australian ePortfolio Project. Higher Education Research \& Development, 29(2): 179-193.https://doi.org/10.1080/07294360903510582

[25] Lee, C. B., \&Teo, T. (2011). An exploratory study on pre-service teachers' perceptions of the differences between knowledge and belief. Asia-Pacific Education Researcher, 20(1), 93-102. Retrieved from www.scopus.com.

[26] Lee, Y., \& Lee, J. (2014). Enhancing pre-service teachers' self-efficacy beliefs for technology integration through lesson planning practice. Computers and Education, 73, 121-128. https://doi.org/10.1016/j.compedu.2014.01.001

[27] Crompton, H. (2015). Pre-service teachers' developing technological pedagogical content knowledge (tpack) and beliefs on the use of technology in the k-12 mathematics classroom: A review of the literature. Technological pedagogical content knowledge: Exploring, developing, and assessing TPCK (pp. 239-250) https://doi.org/10.1007/978-1-4899$8080-9 \quad 12$

[28] Deechuay, N., Koul, R., Maneewan, S., \&Lerdpornkulrat, T. (2016). Relationship between gender identity, perceived social support for using computers, and computer self-efficacy and value beliefs of undergraduate students. Education and Information Technologies, 21(6), 1699-1713. https://doi.org/10.1007/s10639-015-9410-8

[29] Er, E., \& Kim, C. M. (2017). Episode-centered guidelines for teacher belief change toward technology integration. Educational Technology Research and Development, 65(4), 10411065. https://doi.org/10.1007/s11423-017-9518-1

[30] Barrett, H. (2000). Create Your Own Electronic Portfolio. Learning \& Leading with Technology, 27(7), 14-21.

[31] Forker, E.J. \& McDonald, E.M. (1996). Perspective on Assessment. Methodology Trends in the Healthcare Profession: Portfolio Assessment. Nurse Educator. 21,5, pp.9-10 https://doi.org/10.1097/00006223-199609000-00006

[32] Klenowski, V. (1998). Guideline for Portfolio Use in Initital Teacher Education. [Online] retrieve from: http://www.ied.edu.hk/cric/series/pdf/98 papr1.pdf

[33] Koraneekij, P. (2007). Development of electronic portfolio model using self-assessment to enhance student teacher's critical thinking. Faculty of Education, Chulalongkorn University.

[34] Van der Schaaf, M., Donkers, J., Slof, B., Moonen-van Loon, J., van Tartwijk, J., Driessen, E., Ten Cate, O. (2017). Improving workplace-based assessment and feedback by an Eportfolio enhanced with learning analytics. Educational Technology Research and Development. 65(2). 359-380. Retrieve from: https://doi.org/10.1007/s11423-016-9496-8

[35] Khlaisang, J. (2012). Development of Pedagogical Blended E-Learning Model Using Cognitive Tools Based Upon Constructivist Approach for Knowledge Construction in Higher Education. Proceedings of the Fourth International e-Learning Conference 2012, organized by the Thailand Cyber University Project, Office of the Higher Education Commission, Bangkok, Thailand, June 14, 2012.

[36] Thorne, C.J., Lockey, A.S., Kimani, P.K., Bullock, I., Hampshire, S., Begum-Ali, S., \& Perkins, G.D. (2017). e-Learning in Advanced Life Support-What factors influence assessment outcome? Resuscitation, 114: 83-91.https://doi.org/10.1016/j. resuscitation.2017.02.014

[37] Aydin, S. (2012). A review of research on Facebook as an educational environment. Educational Technology Research and Development, 60(6): 10931106.https://doi.org/10.1007/s11423-012-9260-7

[38] Pilgrim, M., Hornby, G., Everatt, J., \& Macfarlane, A. (2017). Evaluation of an innovative programme for training teachers of children with learning and behavioural difficulties in 
Paper-Students Beliefs Regarding the Use of E-portfolio to Enhance Cognitive Skills...

New Zealand. Educational Review, 69(3): 337-348.https://doi.org/10.1080/00 131911.2016 .1218443

[39] Bonk, C. J. \& Graham, C. R. (2005). Future Directions of Blended Learning In Higher Education and Workplace Learning Settings. In Bonk, C. J. \& Graham, C. R. (Eds.). Handbook of Blended Learning: Global Perspectives, Local designs. Wiley, John \& Sons,

[40] Chan, Z. C. Y. (2017). A qualitative study on using concept maps in problem-based learning. Nurse EducPract 24: 70-76.https://doi.org/10.1016/j.nepr.2017.04.008

[41] Hamdy, H., Al-Moslih, A., Tavarnesi, G., \&Laus, A. (2017). Virtual patients in problembased learning. Medical Education, 51(5): 557-558.https://doi.org/10.1111/medu.13293

[42] Smith, C. S. \& Hung, L.-C. (2017). Using problem-based learning to increase computer self-efficacy in Taiwanese students. Interactive Learning Environments, 25(3): 329342.https://doi.org/10.1080/10494820.2015.1127818

[43] Chua, K. J., Yang, W. M., \& Leo, H. L. (2014). Enhanced and conventional project-based learning in an engineering design module. International Jour nal of Technology and Design Education, 24(4), 437-458. https://doi.org/10.1007/ $\underline{\text { s10798-013-9255-7 }}$

[44] Wu, C., Hwang, G., Kuo, F., \& Huang, I. (2013). A mindtool-based collaborative learning approach to enhancing students' innovative performance in management courses. Australasian Journal of Educational Technology, 29(1), 128-142. Retrieved from www.scopus.com.https://doi.org/10.14742/ajet.163

[45] Davis, E. J., Pauls, S., \& Dick, J. (2017). Project-based learning in undergraduate environmental chemistry laboratory: Using EPA methods to guide student method development for pesticide quantitation. Journal of Chemical Education, 94(4), 451-457. https://doi.org/10.1021/acs.jchemed.6b00352

[46] Ludwig, P., Tongen, A., \& Walton, B. (2017). Two project-based strategies in an interdisciplinary mathematical modeling in biology course. PRIMUS, 1-18. https://doi.org/10.1080/10511970.2016.1246495

[47] Loughran, J. J. (2008). Toward a better understanding of teaching and learning about teaching. In Marilyn Cochran-Smith, Sharon FeimanNemser\& D. John McIntyre \& Kelly E. Demers (Eds.), Handbook of Research on Teacher Education: Enduring issues in changing contexts. London: Routledge press.

[48] McKeachie, W. J. (2006). McKeachie's Teaching Tips, Strategies, Research, and Theory for College and University Teachers, Twelfth edition. Boston, MA: Houghlin Mifflin.

[49] Hallinger, P. \& Bridges, E. M. (2017). A Systematic Review of Research on the Use of Problem - Based Learning in the Preparation and Development of School Leaders. Educational Administration Quarterly, 53(2): 255-288.https://doi.org/10.1177/ $0013161 X 16659347$

[50] Hou, H., Yu, T., Wu, Y., Sung, Y., \& Chang, K. (2016). Development and evaluation of a web map mind tool environment with the theory of spatial thinking and project-based learning strategy. British Journal of Educational Technology, 47(2): 390402.https://doi.org/10.1111/bjet.12241

[51] Intel Corporation. (2007). Designing Effective Projects. Retrieve from http://www.huso.buu.ac.th/file/2559/ActiveLearning/Document/11.Design\%20Effective\% 20Proj.pdf.

[52] Chu, S. K. W., Zhang, Y., Chen, K., Chan, C. K., Lee, C. W. Y., Zou, E., \& Lau, W. (2017). The effectiveness of wikis for project-based learning in different disciplines in higher education. Internet and Higher Education, 33, 49-60. https://doi.org/10.1016/j .iheduc.2017.01.005 
[53] Han, S. (2017). Korean students' attitudes toward STEM project-based learning and major selection. KuramVeUygulamadaEgitimBilimleri, 17(2), 529-548. https://doi.org/10.12 738/estp.2017.2.0264

[54] Biasutti, M. \& El-Deghaidy, H. (2015). Interdisciplinary project-based learning: an online wiki experience in teacher education. Technology, Pedagogy and Education 24(3): 339355https://doi.org/10.1080/1475939X.2014.899510.

[55] Ruggiero, D. \& Boehm, J. D. (2017). Project-based learning in a virtual internship programme: A study of the interrelated roles between intern, mentor and client. Computers \& Education, 110: 116-126.https://doi.org/10.1016/j.compedu.2017.03.011

[56] Koraneekij, P and Khlaisang, J. (2015). Development of Learning Outcome Based EPortfolio Model Emphasizing on Cognitive Skills in Pedagogical Blended E-Learning Environment for Undergraduate Students at Faculty of Education, Chulalongkorn University. Procedia-Social and Behavioral Sciences. 174(2015): 805-813.https://doi.org/10.1 016/j.sbspro.2015.01.664

[57] Cargas, S., Williams, S., \& Rosenberg, M. (2017). An approach to teaching critical thinking across disciplines using performance tasks with a common rubric. Thinking Skills and Creativity, 26, 24-37. https://doi.org/10.1016/j.tsc.2017.05.005

[58] Fong, C. J., Kim, Y., Davis, C. W., Hoang, T., \& Kim, Y. W. (2017). A meta-analysis on critical thinking and community college student achievement. Thinking Skills and Creativity, 26, 71-83 https://doi.org/10.1016/j.tsc.2017.06.002

[59] Nahum, O. E., and Hadas, Y. (2018). A framework for solving real-time multi-objective $V R P$ https://doi.org/10.1007/978-3-319-57105-8 5

[60] Marques, O. (2018). Using games to solve challenging multimedia problems. https://doi.org/10.1007/978-981-10-3373-5 2

[61] Wang, F. H. (2017). An exploration of online behaviour engagement and achievement in flipped classroom supported by learning management system. Computers and Education, 114, 79-91. https://doi.org/10.1016/j.compedu.2017.06.012

[62] De Rooij, A., Corr, P. J., \& Jones, S. (2017). Creativity and emotion: Enhancing creative thinking by the manipulation of computational feedback to determine emotional intensity. Paper presented at the C and C 2017 - Proceedings of the 201 7 ACM SIGCHI Conference on Creativity and Cognition, 148-157. https://doi.org/10.1145/3059454.3059469

[63] Pitts, C., Anderson, R., \& Haney, M. (2017). Measures of instruction for creative engagement: Making metacognition, modeling and creative thinking visible. Learning Environments Research, 1-17. https://doi.org/10.1007/s10984-017-9238-9

[64] Faul, F., Erdfelder, E., Buchner, A., \& Lang, A. (2009). Statistical power analyses using G*Power 3.1: Tests for correlation and regression analyses. Behavior Research Methods. 41(4).1149-1160.https://doi.org/10.3758/BRM.41.4.1149

[65] Wongwanich, S. (2015). Needs assessment research. Bangkok: Chulalongkorn University Press.

[66] Bleasel, J., Burgess, A., Weeks, R., \&Haq, I. (2016). Feedback using an ePortfolio for medicine long cases: Quality not quantity. BMC Medical Education, 16(1) https://doi.org/10.1186/s12909-016-0801-3

\section{Authors}

Prakob Koraneekij is an Associate Professor at the Department of Educational Technology and Communications, Chulalongkorn University, Bangkok, Thailand. His 
Paper-Students Beliefs Regarding the Use of E-portfolio to Enhance Cognitive Skills...

research interests include E-portfolio, E-learning, Mobile Learning, Blended Learning Environment, and MOOCs (prakob.k@chula.ac.th).

Jintavee Khlaisangis an Associate Professor at the Department of Educational Technology and Communications, Chulalongkorn University, Bangkok, Thailand. Her research interests include E-learning, Flipped classroom, Blended Learning Environment, Virtual Learning Environment, Ubiquitous Learning, and MOOCs (jintavee.m@g.chula.edu).

Article submitted 22 January 2018. Resubmitted 19 June and 10 September 2018. Final acceptance 10 September 2018. Final version published as submitted by the authors. 